\title{
Article \\ Comparison of Thyroid Hormone Levels between Women Farmers and Non-Farmers in Banten Indonesia
}

\author{
Dian Mardhiyah ${ }^{1, *}$, Wan Nedra Komaruddin ${ }^{2}$, Fasli Nedra Jalal ${ }^{3}$, Sri Wuryanti ${ }^{3}$, Syukrini Bahri ${ }^{4}$, \\ Qomariah Qomariah ${ }^{5}$, Insan Sosiawan ${ }^{5}$, Himmi Marsiati ${ }^{5}$, Legiono Legiono ${ }^{5}$, Harliansyah Hanif ${ }^{6}$, \\ Susan Woskie ${ }^{7}$ (D) and Pornpimol Kongtip ${ }^{8}$ (D)
}

\section{check for}

updates

Citation: Mardhiyah, D.; Komaruddin, W.N.; Jalal, F.N.;

Wuryanti, S.; Bahri, S.; Qomariah, Q.; Sosiawan, I.; Marsiati, H.; Legiono, L.; Hanif, H.; et al. Comparison of

Thyroid Hormone Levels between Women Farmers and Non-Farmers in Banten Indonesia. Int. J. Environ. Res. Public Health 2021, 18, 6618

https://doi.org/10.3390/ijerph18126618

Academic Editor: Claudio Colosio

Received: 7 May 2021

Accepted: 8 June 2021

Published: 19 June 2021

Publisher's Note: MDPI stays neutral with regard to jurisdictional claims in published maps and institutional affiliations.

Copyright: (C) 2021 by the authors. Licensee MDPI, Basel, Switzerland This article is an open access article distributed under the terms and conditions of the Creative Commons Attribution (CC BY) license (https:// creativecommons.org/licenses/by/ $4.0 /)$
Department of Public Health, YARSI University, Jakarta 10510, Indonesia

2 Department of Pediatric, YARSI University, Jakarta 10510, Indonesia; wan.nedra@yarsi.ac.id

3 Department of Nutrition, YARSI University, Jakarta 10510, Indonesia; fasli.jalal@yarsi.ac.id (F.N.J.); sri.wuryanti@yarsi.ac.id (S.W.)

4 Department of Clinical Pathology, YARSI University, Jakarta 10510, Indonesia; syukrini.bahri@yarsi.ac.id

5 Department of Physiology, YARSI University, Jakarta 10510, Indonesia; qomariyah@yarsi.ac.id (Q.Q.); insan.sosiawan@yarsi.ac.id (I.S.); himmi.marsiati@yarsi.ac.id (H.M.); legiono@yarsi.ac.id (L.L.)

6 Department of Biomedical Science, YARSI University, Jakarta 10510, Indonesia; harliansyah.hanif@yarsi.ac.id

7 Department of Public Health, University of Massachusetts Lowell, Lowell, MA 01854, USA; Susan_Woskie@uml.edu

8 Department of Occupational Health and Safety, Faculty of Public Health, Mahidol University, Bangkok 10400, Thailand; pornpimol.kon@mahidol.ac.th

* Correspondence: dian.mar@yarsi.ac.id or dian_mardhiyah@yahoo.co.id; Tel.: +62-(21)4206675

Abstract: Pesticides are suspected of being endocrine disruptors. This cross-sectional study measured serum samples for levels of thyroid hormones including thyroid stimulating hormone (TSH), triiodothyronine (T3), thyroxine (T4), free T3 (FT3), and free T4 (FT4) among Indonesian female farmers $(n=127)$ and non-farmers $(n=127)$. A questionnaire was used to collect information on demographics and risk factors including work characteristics and frequency, and the use of home and agricultural pesticides. Results showed that there were no significant differences in the distribution of the clinical categories of thyroid levels between farmers and non-farmers except for FT3 and T4. However, in multivariable regression controlling for confounders, FT3 and T4 were significantly higher for farmers compared to non-farmers. In addition, 32\% of farmers had clinically low iodine levels and $49 \%$ of non-farmers had clinically high iodine levels. We conclude that pesticide exposure may not be as important as iodine intake in explaining these findings. We recommend counseling by health workers about the importance of using iodized salt for farmers and counseling about high iodine foods that need to be avoided for non-farmers.

Keywords: thyroid hormone; pesticides; occupational health; agricultural health; female farmers; endocrine disrupters; agricultural worker

\section{Introduction}

In 2020, the Minister of Agriculture in Indonesia stated that the production targets of the country had increased to 59.15 million tons for rice, 30.35 million tons for corn, and 1.29 million tons for soybeans [1]. Along with fertilizer, the use of pesticides forms part of farmers' efforts to control crop pests and increase farm productivity to meet the increasing demands of Indonesia's growing population as well as its export needs. Data on the use of pesticides in Southeast Asia, including in Indonesia, are still very limited, although from 2015-2020, the number of pesticide trademarks increased by 4380 brands [2].

Little research has been done to identify the risks faced by Indonesian farmers using pesticides. In Semarang Indonesia, 13 of the 50 Indonesian chili farmers studied (26\%) reported severe pesticide poisoning and 37 (74\%) reported light poisoning by pesticides [3]. In a study of 70 horticulture farmers in Magelang, Central Java, 14.3\% reported pesticide 
poisoning and $34 \%$ had a balance disorder as tested by the Romberg Test [4]. According to the Directorate General of Food Crops, in 2013, 19 farmers (47.5\%) had poisoning due to pesticides and 17 farmers (42.5\%) suffered from anemia in Gombong Village, Indonesia [1].

Some pesticides have been identified as potential endocrine disrupting chemicals (EDCs); i.e., chemicals that can interfere with the synthesis, secretion, transport, metabolism, binding, and elimination of hormones in the body [5]. The hypothalamus pituitary thyroid axis is one endocrine system that is at risk of experiencing a negative impact due to pesticide exposure [5-7]. Hypothyroidism is a condition in which the thyroid gland cannot produce enough hormones (T4 and T3) to meet the body needs [8-10]. If a hypothyroid condition occurs in women, it can result in infertility, spontaneous abortion, fetal growth disorders, placental abruption, and prematurely born babies.

Research in Iowa and North Carolina looked at hypothyroidism and hyperthyroidism among female spouses of pesticide applicators $(n=16,529)$ who were enrolled in the U.S. Agricultural Health Study. They assessed the risk of thyroid disease in relation to ever using herbicides, insecticides, fungicides, and fumigants. The prevalence of selfreported clinically diagnosed thyroid disease was $12.5 \%$ among those reporting pesticide use, and the prevalence of hypothyroidism and hyperthyroidism was $6.9 \%$ and $2.1 \%$, respectively [9]. A study of Indonesian women found an increased risk of thyroid hormone disorders associated with long term pesticide exposure [11].

The Inter-Census Agricultural Survey in 2018 in Indonesia reported that there were $8,051,328$ female farmers in Indonesia [12], but little research has been done to investigate the health risks they face as agricultural workers. The objective of this study was to evaluate whether female farmers in one province in Indonesia have significantly different thyroid hormone profiles than female non-farmers in the same region.

\section{Materials and Methods}

\subsection{Study Population}

In Banten Province, where this study was conducted, there were 184,753 female farmers (25\% of all farmers) [12]. In 2018, rice productivity in Banten was 1,603,550 tons [13], making this area a regional rice supplier, with $2-3$ rice planting periods per year.

This cross-sectional study was assisted by community health workers, health workers from the primary health service, and community leaders in the area. The inclusion criteria included female farmers with children aged newborn to 59 months, without thyroid disease, living in an agricultural area, and participating in the growing of farm crops. We recruited non-agricultural female workers with children aged newborn to 59 months, without thyroid disease from a district in Banten Province which borders the city of Jakarta (this area has few agricultural areas). This study was approved by The Ethical Committee Research Institute YARSI University, (038/KEP-UY/BIA-IV/2019).

\subsection{Data Collection}

The study was conducted from August 2019 to December 2019. Farmers from 3 villages in Pandeglang district were invited to participate in the study and to come to their village hall to receive a health education program from the researchers. With the research team, they filled out questionnaires and underwent physical examinations. The questionnaire consisted of respondent characteristics and risk factors consisting of age, education, occupation, family income, reproductive history (miscarriage, preterm birth, and low birth weight), hand washing habits, vegetable washing habits, working hours, working days, years of work, and use of insecticides at home.

Data on weight, height, BMI and body composition (Tanita model DC-360, Tanita Europe BV, Hoogoorddreef, Amsterdam, The Netherlands), blood pressure (taken twice at $10 \mathrm{~min}$ intervals and averaged), spot urine samples, and blood samples were obtained during the physical examination.

Serum was extracted from the blood sample in a non-heparin vacutainer tube stored at $-20{ }^{\circ} \mathrm{C}$ until analysis. All serum samples were analyzed at YARSI Hospital using an 
automatic quantitative enzyme immunoassay (Enzyme Linked Fluorescent Assay) on the VIDAS ${ }^{\circledR}$ biomerieux (REF 410417, bioMérieux SA, Marcy-I'Etoile, France) instrument for the determination of free thyroxine (FT4), thyroid stimulating hormone (TSH), triiodothyronine (T3), thyroxine (T4), and free triiodothyronine (FT3). The limit of detection was $0.05 \mu \mathrm{IU} / \mathrm{mL}$ for TSH [14], <0.7 pmol/L for FT3 [15], $0.07 \mathrm{ng} / \mathrm{dL}$ for FT4 [16], $0.05 \mathrm{nmol} / \mathrm{L}$ for T3 [17], and $37.49 \mathrm{nmol} / \mathrm{L}$ for T4 [18].

Urine samples were sent to the Ministry of Health of the Republic of Indonesia Health Laboratory of the Magelang Health Research and Development Agency to measure urinary iodine. This examination used IK-7.2.7 UIE (spectrophotometric method) with a normal range of $100-199 \mu \mathrm{g} / \mathrm{L}$.

\subsection{Study Variables}

The clinical criteria for high blood pressure used Indonesian guidelines for measuring hypertension (normal values of $<90 \mathrm{mmHg}$ for diastole and $<140 \mathrm{mmHg}$ for systole) [19]. Body mass index scores were divided into underweight $<18.4$, normal weight $18.5-25$, and overweight $>25.1[20,21]$. Measurement criteria for female body fat percentage were based on a normal value of $<32 \%$ [22]. The normal value of urinary iodine excretion (UIE) was 100-199 $\mu / L$ [23]. The measurement of improper hand washing included self-reports of not washing hands in running water using soap. Measurements of insecticide use at home included using mosquito repellent products in the form of lotion, spray, electric plug-in vaporizers, and coils. Agricultural pesticide exposure was defined as "high" for respondents who self-reported that they applied pesticides by spraying, mixed or washed pesticide spray equipment, or applied pesticide tablets or powder.

\subsection{Statistical Analysis}

The descriptive analysis of demographic characteristics and clinical outcomes of thyroid hormone levels was performed using Chi Square and independent t test using SPSS Statistics for Windows, version 18 (SPSS Inc., Chicago, Ill., USA). Comparison of thyroid hormone levels between farmers and non-farmers used a general linear model with the $\log$ (base 10) of thyroid hormone levels (TSH, T3, T4, FT3, and FT4) as the outcome, due to the skewed distribution of thyroid levels. The univariate model examined other potential covariates such as age, education level, family income, preterm birth, low birth weight, miscarriage, improper hand washing, number of current work hours, number of current work days, years of work, use of insecticides at home, and dichotomous variables based on clinical normal vs. abnormal levels including body fat percentage, BMI, and blood pressure. When the parameters were significantly associated ( $p$ value $<0.05$ ) with thyroid levels in univariate models, they were considered for inclusion in the multivariable linear model if they were not colinear. The final models included work hours per day, years of work, and blood pressure.

\section{Results}

\subsection{Demographics and Risk Factors}

The demographics of farmers and non-farmers are shown in Table 1. Most of the respondents were in the age range $26-35$ years (61\% of farmers and 50\% of non-farmers were in this range), and there was no statistically significant difference in age between the groups. The rate of completion of primary school education for farmers was $67 \%$, while $65 \%$ of non-farmers received secondary education, resulting in a significant difference in educational level between the groups. Significant differences were also found in family income, where $26 \%$ of farmers reported insufficient income and debt, while $48 \%$ of nonfarmers reported sufficient income and savings. There was a significant difference in the percentage of women reporting premature birth (16\% for farmers vs. $6 \%$ for nonfarmers), but no significant differences in self-reported low birth weight or miscarriages. The working hours per day of farmers and non-farmers were significantly different, with most farmers working fewer than $8 \mathrm{~h}$ /day and most non-farmers working more than $8 \mathrm{~h}$ a 
day. Similarly, the working days per week were significantly different between the groups, with almost all non-farmers working $\geq 5$ days per week, while only about half ( $49 \%)$ of farmers worked $\geq 5$ days per week. There was a significant difference between farmers and non-farmers in the years they had been working. Among non-farmers, $28 \%$ reported working for $<3$ years, while only $13 \%$ of farmers reported working for $<3$ years (Table 1 ).

Table 1. Demographics and risk factors of farmers $(n=127)$ and non-farmers $(n=127)$.

\begin{tabular}{|c|c|c|c|c|c|}
\hline Variables & Farmers & Non-Farmers & $p$-Value & OR & CI \\
\hline \multicolumn{6}{|l|}{ Age } \\
\hline Mean age (SD) & $32.8(6.620)$ & $31.56(5.820)$ & \multirow{6}{*}{0.099} & \multirow{6}{*}{ NA } & \\
\hline (Min-max) (year) & $(19-47)$ & $(21-44)$ & & & \\
\hline $17-25$ & $19(15.0 \%)$ & $18(14.2 \%)$ & & & \\
\hline $26-35$ & $78(61.4 \%)$ & $63(49.6 \%)$ & & & \\
\hline $36-45$ & $30(23.6 \%)$ & $44(34.6 \%)$ & & & \\
\hline $46-55$ & $0(0.0 \%)$ & $2(1.6 \%)$ & & & \\
\hline \multicolumn{6}{|l|}{ Educational Level } \\
\hline Low & $85(66.9 \%)$ & $0(0.0 \%)$ & \multirow{3}{*}{0.000} & \multirow{3}{*}{ NA } & \\
\hline Middle & $42(33.1 \%)$ & $83(65.4 \%)$ & & & \\
\hline High & $0(0.0 \%)$ & $44(34.6 \%)$ & & & \\
\hline \multicolumn{6}{|l|}{ Family income } \\
\hline Enough with savings & $25(19.7 \%)$ & $61(48.0 \%)$ & \multirow{3}{*}{0.000} & \multirow{3}{*}{ NA } & \\
\hline Enough without savings & $69(54.3 \%)$ & $65(51.2 \%)$ & & & \\
\hline Not enough with debt & $33(26.0 \%)$ & $1(0.8 \%)$ & & & \\
\hline \multicolumn{6}{|l|}{ Preterm Birth } \\
\hline Yes & $21(16.5 \%)$ & $7(5.5 \%)$ & \multirow{2}{*}{0.005} & \multirow{2}{*}{2.12} & \multirow{2}{*}{$1.105-4.081$} \\
\hline No & $106(83.5 \%)$ & $120(94.5 \%)$ & & & \\
\hline \multicolumn{6}{|l|}{ Low Birth Weight } \\
\hline Yes & $6(4.7 \%)$ & $6(4.7 \%)$ & \multirow{2}{*}{1} & \multirow{2}{*}{1} & \multirow{2}{*}{$0.560-1.785$} \\
\hline No & $121(95.3 \%)$ & $121(95.3 \%)$ & & & \\
\hline \multicolumn{6}{|l|}{ Miscarriage } \\
\hline Yes & $21(16.5 \%)$ & $13(10.2 \%)$ & \multirow{2}{*}{0.140} & \multirow{2}{*}{0.78} & \multirow{2}{*}{$0.579-1.051$} \\
\hline No & $106(83.5 \%)$ & $114(89.8 \%)$ & & & \\
\hline \multicolumn{6}{|l|}{ Improper hand washing } \\
\hline Yes & $70(55.1 \%)$ & $7(5.5 \%)$ & \multirow[t]{2}{*}{0.000} & 7.458 & $3.653-15.223$ \\
\hline No & $57(44.9 \%)$ & $120(94.5 \%)$ & & & \\
\hline $\begin{array}{l}\text { Current Work hours } \\
\text { (hours/day) }\end{array}$ & & & & & \\
\hline Mean $(\mathrm{SD})$ & $4.4(2.202)$ & $8.27(6.661)$ & & & \\
\hline (Min-max) & $(1-9)$ & $(3-24)$ & & & \\
\hline$\geq 8 \mathrm{~h} /$ day & $16(12.9 \%)$ & $46(36.2 \%)$ & & & \\
\hline$<8$ h/day & $111(87.4 \%)$ & $81(63.8 \%)$ & 0.000 & 0.57 & $0.456-0.709$ \\
\hline $\begin{array}{l}\text { Current Work day } \\
\text { (days/week) }\end{array}$ & & & & & \\
\hline Mean (SD) & $4.41(2.395)$ & $6.24(0.774)$ & & & \\
\hline (Min-max) & $(1-7)$ & $(3-7)$ & & & \\
\hline$\geq 5$ days/week & $62(48.8 \%)$ & $126(99.2 \%)$ & 0.000 & 0.02 & $0.003-0.159$ \\
\hline$<5$ days/week & $65(51.2 \%)$ & $1(0.8 \%)$ & & & \\
\hline Years of Work & & & & & \\
\hline Mean (SD) & $9.47(6.976)$ & $5.89(4.172)$ & & & \\
\hline (Min-max) & $(1-30)$ & $(1-21)$ & & & \\
\hline$\geq 3$ years & $110(86.6 \%)$ & $92(72.4 \%)$ & & & \\
\hline$<3$ years & $17(13.4 \%)$ & $35(27.6 \%)$ & 0.005 & 1.48 & $1.160-1.883$ \\
\hline $\mathrm{BMI}\left(\mathrm{kg} / \mathrm{m}^{2}\right)$ & & & & & \\
\hline Underweight & $6(4.7 \%)$ & $9(7.1 \%)$ & & & \\
\hline Normal & $65(51.2 \%)$ & $63(49.6 \%)$ & 0.726 & & \\
\hline Overweight & $56(44.1 \%)$ & $55(43.3 \%)$ & & & \\
\hline
\end{tabular}


Table 1. Cont.

\begin{tabular}{|c|c|c|c|c|c|}
\hline Variables & Farmers & Non-Farmers & $p$-Value & OR & $\mathrm{CI}$ \\
\hline $\begin{array}{c}\text { Blood Pressure }(\mathrm{mmHg}) \\
\text { Abnormal }(\geq 140 \text { and } \geq 90) \\
\text { Normal }(<90 \text { and }<140)\end{array}$ & $\begin{array}{l}42(33.1 \%) \\
85(66.9 \%)\end{array}$ & $\begin{array}{c}20(15.7 \%) \\
107(84.3 \%)\end{array}$ & 0.001 & 1.73 & $1.179-2.532$ \\
\hline $\begin{array}{c}\text { Systolic }(\mathrm{mmHg}) \\
\text { Abnormal }(<90 \text { and } \geq 140) \\
\text { Normal }(90-<140)\end{array}$ & $\begin{array}{c}12(9.4 \%) \\
115(90.6 \%)\end{array}$ & $\begin{array}{c}5(3.9 \%) \\
122(96.1 \%)\end{array}$ & 0.079 & 1.75 & $0.829-3.693$ \\
\hline $\begin{array}{c}\text { Diastolic }(\mathrm{mmHg}) \\
\text { Abnormal }(<65 \text { and } \geq 90) \\
\text { Normal }(65-<90)\end{array}$ & $\begin{array}{l}85(66.9 \%) \\
42(33.1 \%)\end{array}$ & $\begin{array}{c}21(16.5 \%) \\
106(83.5 \%)\end{array}$ & 0.000 & 3.61 & $2.433-5.373$ \\
\hline $\begin{array}{c}\text { Body Fat } \% \\
\text { Abnormal } \geq 32 \% \\
\text { Normal }<32 \%\end{array}$ & $\begin{array}{l}78(61.4 \%) \\
49(38.6 \%)\end{array}$ & $\begin{array}{l}96(75.6 \%) \\
31(24.4 \%)\end{array}$ & 0.015 & 0.732 & $0.576-0.930$ \\
\hline $\begin{array}{c}\text { Insecticide used in home } \\
\text { Yes } \\
\text { No } \\
\end{array}$ & $\begin{array}{l}104(81.9 \%) \\
23(18.1 \%)\end{array}$ & $\begin{array}{l}94(74.0 \%) \\
33(26.0 \%)\end{array}$ & 0.130 & 1.24 & $0.954-1.615$ \\
\hline $\begin{array}{c}\text { Frequency of insecticide use } \\
\text { in home } \\
>5 \text { day/a week } \\
2-4 \text { day/a week } \\
1 \text { day/a week } \\
1-3 \text { times/month } \\
<1 \text { time/month } \\
\text { Never }\end{array}$ & $\begin{array}{c}86(67.7 \%) \\
10(7.9 \%) \\
2(1.6 \%) \\
2(1.6 \%) \\
4(3.1 \%) \\
23(18.1 \%)\end{array}$ & $\begin{array}{c}35(27.6 \%) \\
8(6.3 \%) \\
13(10.2 \%) \\
13(10.2 \%) \\
25(19.7 \%) \\
33(26.0 \%)\end{array}$ & 0.000 & NA & \\
\hline $\begin{array}{c}\text { Hormone FT3 } \\
\text { Hypo }<4 \\
\text { Normal }(4-8.3) \\
\text { Hyper }>8.3\end{array}$ & $\begin{array}{c}81(63.8 \%) \\
46(36.2 \%) \\
0(0.0 \%)\end{array}$ & $\begin{array}{l}116(91.3 \%) \\
9(7.1 \%) \\
2(1.6 \%)\end{array}$ & 0.000 * & NA & \\
\hline $\begin{array}{c}\text { Hormone FT4 } \\
\text { Hypo }<10.6 \\
\text { Normal }(10.6-19.4) \\
\text { Hyper }>19.4 \\
\end{array}$ & $\begin{array}{c}20(15.7 \%) \\
106(83.5 \%) \\
1(0.8 \%)\end{array}$ & $\begin{array}{c}15(11.8 \%) \\
109(85.8 \%) \\
3(2.4 \%)\end{array}$ & $0.646^{*}$ & NA & \\
\hline $\begin{array}{c}\text { Hormone T3 } \\
\text { Hypo }<0.92 \\
\text { Normal }(0.92-2.33) \\
\text { Hyper }>2.33\end{array}$ & $\begin{array}{c}6(4.7 \%) \\
119(93.7 \%) \\
2(1.6 \%)\end{array}$ & $\begin{array}{c}5(3.9 \%) \\
116(91.3 \%) \\
6(4.7 \%)\end{array}$ & $0.446^{*}$ & NA & \\
\hline $\begin{array}{c}\text { Hormone T4 } \\
\text { Hypo }<20 \\
\text { Normal }(60-120) \\
\text { Hyper }>120\end{array}$ & $\begin{array}{c}1(0.8 \%) \\
125(98.4 \%) \\
1(0.8 \%)\end{array}$ & $\begin{array}{c}5(3.9 \%) \\
119(93.7 \%) \\
3(2.4 \%)\end{array}$ & 0.018 * & NA & \\
\hline $\begin{array}{l}\text { Hormone TSH } \\
\text { Hypo }<0.25 \\
\text { Normal }(0.25-5) \\
\text { Hyper }>5\end{array}$ & $\begin{array}{c}0(0.0 \%) \\
126(99.2 \%) \\
1(0.8 \%)\end{array}$ & $\begin{array}{c}2(1.6 \%) \\
125(98.4 \%) \\
0(0.0 \%)\end{array}$ & $0.568 *$ & NA & \\
\hline $\begin{array}{c}\text { Urine Iodine } \\
\text { Hypo }<100 \mu / \mathrm{L} \\
\text { Normal }(100-199 \mu / \mathrm{L}) \\
\text { Hyper }>199 \mu / \mathrm{L}\end{array}$ & $\begin{array}{l}41(32.3 \%) \\
46(36.2 \%) \\
40(31.5 \%)\end{array}$ & $\begin{array}{l}15(11.8 \%) \\
50(39.4 \%) \\
62(48.8 \%)\end{array}$ & 0.000 & NA & \\
\hline
\end{tabular}

${ }^{*}$ Independent $t$ test.

Farmers were significantly more likely to have abnormal blood pressure than nonfarmers, although there was no significant difference in BMI. There was no significant difference in self-reported insecticide use at home, with most of the subjects reporting use ( $82 \%$ of farmers and $74 \%$ of non-farmers). However, farmers reported use of insecticides almost daily $(68 \%)$, whereas $26 \%$ non-farmers never used insecticides-a significant difference. Non-farmers were significantly more likely to have an abnormal body fat percentage than farmers. All respondents reported not smoking or drinking alcohol.

Significant differences in the distribution of thyroid level clinical categories were found for FT3 and T4 between farmers and non-farmers. Non-farmers were more likely to be hypo-thyroid for FT3 and hyper-thyroid for T4, while farmers were more likely to be 
hypo-thyroid for T4 (Table 1). There were no significant differences in the distribution of clinical categories for the hormones FT4, T3, and TSH in farmers and non-farmers. There was a significant difference in the distribution of urinary iodine levels between non-farmers and farmers, with laboratory results showing farmers were more likely to have low urinary iodine levels (Table 1).

Most non-farmers $(72 \%)$ worked in other people's homes as household assistants. For farmer respondents, the most common pesticide use frequency was 2-4 times per season for rice, although there were a few female farmers who did not know when pesticides were applied to the rice crops. Almost all farmers carried out planting and harvesting activities, and a few (7-15\%) worked directly with pesticides (spraying, applying, and cleaning sprayers) (Table 2).

Table 2. Kinds of work for farmers $(n=127)$.

\begin{tabular}{cc}
\hline Work & Yes \\
\hline Planting & $103(81.1 \%)$ \\
Fertilization & $36(28.3 \%)$ \\
Apply pesticide tablets & $9(7.1 \%)$ \\
Application of pesticide powder & $18(14.2 \%)$ \\
Spraying pesticides & $19(15.0 \%)$ \\
Mixing pesticides & $15(11.8 \%)$ \\
Wash the sprayer & $19(15.0 \%)$ \\
Remove the weeds & $65(51.2 \%)$ \\
Harvest & $102(80.3 \%)$ \\
\hline
\end{tabular}

Most farmers reported that they went to the fields wearing long trousers and long sleeves, although quite a number wore household clothes. Very few reported using any form of personal protective equipment when working in the field.

\subsection{Comparison of Thyroid Hormones between Farmers and Non-Farmers}

A simple comparison between the means of the log (base 10) of thyroid hormone levels for farmers versus non-farmers found significant differences for FT3 and T4, with levels of these hormones being higher in farmers (Table 3).

Table 3. Thyroid hormones for farmers $(n=127)$ and non-farmers $(n=127)$.

\begin{tabular}{|c|c|c|c|c|}
\hline $\begin{array}{l}\text { Thyroid } \\
\text { Hormones }\end{array}$ & Farmers & Non-Farmers & $\begin{array}{c}\text { Mean * Difference }(95 \% \text { CI } \\
\text { of the Difference) }\end{array}$ & $p$-Value * \\
\hline $\begin{array}{c}\text { FT3 }(\mu \mathrm{IU} / \mathrm{mL}) \\
\text { Geometric mean } \\
\text { Min-max }\end{array}$ & $\begin{array}{c}1.61 \\
1.35-1.90\end{array}$ & $\begin{array}{c}1.52 \\
1.24-2.65\end{array}$ & $0.94(0.92-0.96)$ & 0.000 \\
\hline $\begin{array}{l}\text { FT4 }(\mu \mathrm{IU} / \mathrm{mL}) \\
\text { Geometric mean } \\
\text { Min-max }\end{array}$ & $\begin{array}{c}2.52 \\
2.14-2.99\end{array}$ & $\begin{array}{c}2.56 \\
2.01-3.44\end{array}$ & $1.01(0.10-1.03)$ & 0.118 \\
\hline $\begin{array}{c}\mathrm{T} 3(\mu \mathrm{IU} / \mathrm{mL}) \\
\text { Geometric mean } \\
\text { Min-max }\end{array}$ & $\begin{array}{c}1.15 \\
0.90-1.37\end{array}$ & $\begin{array}{c}1.14 \\
0.93-1.75\end{array}$ & $0.99(0.97-1.02)$ & 0.528 \\
\hline $\begin{array}{c}\mathrm{T} 4(\mu \mathrm{IU} / \mathrm{mL}) \\
\text { Geometric mean } \\
\text { Min-max }\end{array}$ & $\begin{array}{c}5.02 \\
4.41-5.76\end{array}$ & $\begin{array}{c}4.63 \\
0.95-6.37\end{array}$ & $0.92(0.87-0.97)$ & 0.003 \\
\hline $\begin{array}{l}\text { TSH }(\mu \mathrm{IU} / \mathrm{mL}) \\
\text { Geometric mean } \\
\text { Min-max }\end{array}$ & $\begin{array}{c}1.14 \\
0.62-2.10\end{array}$ & $\begin{array}{c}1.01 \\
0.43-1.75\end{array}$ & $0.96(0.91-1)$ & 0.104 \\
\hline
\end{tabular}


Multivariable linear regression models for logs (base 10) of FT3, FT4, T3, T4 and TSH were adjusted for other covariates (number of current work hours/day, years of work, and blood pressure). Since these are log linear models, the parameter estimates were exponentiated to become a multiplier, showing that the hormone levels of conventional farmers were significantly higher-i.e., by a factor of 1.06 for FT3 and T4 - and significantly lower for farmers for urinary iodine (Table 4).

Table 4. Comparison of log (10) thyroid hormone levels for farmers versus non-farmers using a generalized linear model *.

\begin{tabular}{cc}
\hline Thyroid Hormones & $\operatorname{Exp} \beta(\mathbf{9 5} \% \mathbf{C I})$ \\
\hline FT3 & $1.056(1.030-1.084)$ \\
FT4 & $0.984(0.966-1.004)$ \\
T3 & $1.016(0.989-1.043)$ \\
T4 & $1.058(1.027-1.091)$ \\
TSH & $1.023(0.974-1.073)$ \\
Iodine Urine & $0.866(0.811-0.925)$ \\
\hline
\end{tabular}

* All models controlled for work hours per day, years of work, and blood pressure.

\subsection{Pesticides Exposure to Farmers}

"High" pesticide exposures were assigned when farmers self-reported performing activities such as pesticide spraying, mixing pesticides, washing spray equipment, or applying pesticide tablets or pesticide powder. In this study, there were 28 farmers with high pesticide exposure. We did not find a significant difference between the clinical distributions of farmer thyroid hormones with high vs. low pesticide exposure (Table 5).

Table 5. Pesticides exposure vs. hormones and urine iodine in farmers $(n=127)$.

\begin{tabular}{|c|c|c|c|}
\hline \multirow{2}{*}{ Thyroid Hormones } & \multicolumn{2}{|c|}{ Pesticides Exposure } & \multirow{2}{*}{$p$-Value } \\
\hline & High $(n=28)$ & Low $(n=99)$ & \\
\hline \multicolumn{4}{|l|}{ Hormone FT3 } \\
\hline Нуро < 4 & $18(64.3 \%)$ & $63(63.6 \%)$ & \multirow[b]{2}{*}{0.950} \\
\hline Normal (4-8.3) & $10(35.7 \%)$ & $36(36.4 \%)$ & \\
\hline \multicolumn{4}{|l|}{ Hormone FT4 } \\
\hline Нуро < 10.6 & $3(10.7 \%)$ & $17(17.2 \%)$ & \multirow{3}{*}{$0.343 *$} \\
\hline Normal (10.6-19.4) & $25(89.3 \%)$ & $81(81.8 \%)$ & \\
\hline Hyper $>19.4$ & $0(0.0 \%)$ & $1(1.0 \%)$ & \\
\hline \multicolumn{4}{|l|}{ Hormone T3 } \\
\hline Нyро $<0.92$ & $2(7.1 \%)$ & $4(4.0 \%)$ & \multirow{3}{*}{0.857 * } \\
\hline Normal (0.92-2.33) & $26(92.9 \%)$ & $93(93.9 \%)$ & \\
\hline Hyper $>2.33$ & $0(0.0 \%)$ & $2(2.0 \%)$ & \\
\hline \multicolumn{4}{|l|}{ Hormone T4 } \\
\hline Normal (60-120) & $28(100 \%)$ & $98(99.0 \%)$ & \multirow{2}{*}{$1 * *$} \\
\hline Hyper $>120$ & $0(0.0 \%)$ & $1(1.0 \%)$ & \\
\hline \multicolumn{4}{|l|}{ Hormone TSH } \\
\hline Normal (0.25-5) & $28(100 \%)$ & $98(99.0 \%)$ & \multirow{2}{*}{$1 * *$} \\
\hline Hyper $>5$ & $0(0.0 \%)$ & $1(1.0 \%)$ & \\
\hline \multicolumn{4}{|l|}{ Urine Iodine } \\
\hline Нypo $<100$ & $9(32.1 \%)$ & $32(32.3 \%)$ & \multirow{3}{*}{0.257} \\
\hline Normal (100-199) & $7(25.0 \%)$ & $39(39.4 \%)$ & \\
\hline Hyper > 199 & $12(42.9 \%)$ & $28(28.3 \%)$ & \\
\hline
\end{tabular}

\section{Discussion}

The farmers in this study were more likely to have a low level of education (67\%), which was inversely proportional to non-farmers, who were more likely to have a middle 
level of education (65\%). This is in accordance with the research of Kongtip (2018), which showed that conventional and organic farmers in Thailand have a low education level of $57 \%$ and $55 \%$, respectively. A quarter of the farmers in this study reported that their income was insufficient for daily life and that they had debt, which was in line with findings in Thailand, where $35 \%$ of conventional farmers reported insufficient income with debt [24].

The rate of preterm birth among farmers in this study was quite high $(16.5 \%)$, and there was a 2.12-fold higher risk of preterm birth among farmers compared to non-farmers. Women farmers in Indonesia still perform activities on the farm until birth. This is consistent with research by Anand (2017), which found that women exposed to pesticides were 1.7 times more likely to give birth to preterm babies than women not exposed to any pesticides [25]. In California, it was reported that exposure to pesticides (e.g., glyphosate, paraquat, imidacloprid) in the first and second trimesters of pregnancy can slightly increase (5-7\%) the incidence of preterm birth [26].

We found that the prevalence of hypertension was $33 \%$ among farmers and $16 \%$ among non-farmers. This is in accordance with the work of Riskesdas (2018), where the prevalence of hypertension in the rural population was $33.7 \%$. This is compared to the population of all farmers in Indonesia, where the prevalence of hypertension as a whole is $36 \%$, while for other workers such as laborers, household assistants, and drivers, the prevalence of hypertension is $30 \%$ [27]

The women farmers in this study did not work in the rice fields all day long. This can be seen from the average hours per day, which reached $4.4 \mathrm{~h}$ (min-max: 1-9 $\mathrm{h}$ per day). They worked from morning to noon in the fields, and after lunch in the fields, they went home to care for their children and the household and did not return to the fields. However, male farmers will continue to work after lunch. When having lunch in the field, 55\% of women farmers did not wash their hands properly before eating. From the interviews, many of the farmers washed their hands using water from the fields or used limited quantities of drinking water brought from home and did not use soap.

In this study, only $15 \%$ of female farmers sprayed pesticides, because usually men spray the crops in the fields (Table 4). The women mostly performed planting and harvesting, while some farmers applied fertilizer and removed weeds. Many farmers only wore long sleeves and trousers when working. It was also found that $82 \%$ of farmers were exposed to insecticides used in the home. This is because they lived near rice fields and there was a large number of mosquitoes; thus, many of the farmers used lotion (diethyltoluamid (DEET), spray (d-fenotrin, sipermetrin, imiprotrin, praletrin, transflutrin and $\mathrm{d}$-allethrin), plug in vaporizers (d-allethrin, transflutrin), and mosquito coils (piretrum, piretrin, $\mathrm{d}$-allethrin, and esbiotrin) to repel mosquitoes.

Many $(36 \%)$ of the non-farmers worked $\geq 8 \mathrm{~h}$ per day, while most farmers worked $<8 \mathrm{~h} /$ day $(87 \%)$. This was likely due to most of the non-farmers working in other people homes as household assistants, where working hours can be extended. This contrasts with Kongtip's research (2018), where most agricultural workers in Thailand worked 8-10 h per day [28].

We found that $63 \%$ of farmers were hypothyroid for FT3 and 16\% were hypothyroid for FT4, but there were few significant differences in the distribution of clinical thyroid measures between the farmers and non-farmers. However, in models that include covariates, FT3 and T4 were significantly higher for farmers compared to non-farmers (Table 4). This can be explained in part by non-farmers being more likely to be hypothyroid for FT3 (Table 1). These findings of higher FT3 and T4 in farmers are in line with the work of Kongtip (2019), which reported an increase in TSH, FT3, T3, and T4 levels in conventional farmers relative to organic farmers in Thailand [6,7]. The higher frequency of hypothyroid for FT3 in nonfarmers should be further explored, because a study by Chavez (2013) showed that $11.7 \%$ of respondents with complex inflammatory malnutrition syndrome had a low FT3 level, and this was also associated with IL-6, C-reactive protein, and albumin [29]. Low FT3 is included in non-thyroid disease (NTI), which is a counter-regulatory response that causes a waste of energy and protein in acute and chronic stress conditions, such as uncontrolled 
diabetes mellitus with ketoacidosis, myocardial infarction, and severe myocardial ischemia, and in almost all severe diseases [30,31]. Xue (2017) study found that low FT3 was a worse predictor of health-related quality of life (HRQOL) in Acute Coronary Syndrome (ACS) patients treated with drug-eluting stents (DES) [32]. Blood sampling in this study was conducted in August to December, when the climate was changing to the rainy season. This may have affected their health condition. However, in this study, we did not ask respondents about other health conditions and did not carry out nutritional examinations.

The finding of significant differences in thyroid levels between farmers and nonfarming women is important in part because the extent of pesticide exposure does not differ greatly between them. Women farmers in this area generally do not spray pesticides directly. Only 28 (22\%) of the farmers reported high pesticide exposure activities. In general, pesticides are not widely used, since only $42 \%$ of the farmers reported that pesticides were used in the fields 2-4 times per growing season. In addition, women farmers average only $4.4 \mathrm{~h}$ per day and 4.4 working days per week in the fields and primarily perform planting and harvesting. From the interviews conducted, we understand that during busy periods in the fields, such as during planting and harvesting, the women often take their children to the fields while working so that they can perform both childcare and farming responsibilities at the same time.

Perhaps one explanation for the differences between farmers' and non-farmers' thyroid levels is the significant difference in the distribution of urinary iodine levels. Laboratory results showed $32 \%$ of farmers had low urinary iodine levels and $49 \%$ of non-farmers had high iodine levels (Table 1), and even after controlling for covariates, urinary iodine was significantly lower in farmers than in non-farmers (Table 4). Insufficient iodine intake, leading to iodine deficiency, can manifest as hypothyroidism [33,34]. Although our cohort farmers tended to have higher thyroid levels (FT3 and T4) than non-farmers (Tables 3 and 4 ), 63\% of farmers were considered clinically hypothyroid for FT3 and 16\% were clinically hypothyroid for FT4 (Table 1). Selenium, iron, and vitamin A deficiencies can also exacerbate the effects of iodine deficiency since glutathione peroxidase and deiodinase are selenium-dependent enzymes [35]. Another study conducted in Prambanan District, Indonesia, which is an agricultural area and an endemic area for iodine deficiency, found that $15.7 \%$ of female respondents aged 18-45 years experienced iodine deficiency [36]. If this condition occurs in pregnant women, it will result in neonatal physical disabilities, mental disabilities, and neurological disorders [23,35].

In this study, we did not ask about food intake; thus, further research is needed to determine the cause of low iodine levels in farmers. Several types of food can interfere with thyroid metabolism (e.g., cabbage, kale, cauliflower, broccoli, cassava, peanuts, sweet potatoes, and others) [35]. In our study, we also found a rate of $16 \%$ of preterm birth in farmers. According to Gargari research, iodine deficiency in pregnant women increases the risk of premature birth 3.3-fold [37]. Government iodination programs using iodized salt are encouraged, and iodized salt is inexpensive and easy to obtain in Indonesia.

Meanwhile, for non-farmers, $49 \%$ had high urine iodine content. This condition is related to the consumption of foods that are high in iodine. The main sources of iodine include salt, dairy products, and bread, or those naturally abundant in micronutrients, such as seafood [38]. Almost all seafood is high in iodine [35]. In America, the major sources of high-iodine foods come from milk and bread [35,38]. In Japan, seaweed is a popular food. Thyrotoxicosis cases have been widely reported, including one woman who drank tea containing seaweed for 4 weeks [38].

Limitations of this study include the fact that it used only a single cross-sectional measurement of thyroid hormone levels. In addition, we estimated pesticide exposure using a questionnaire for home and agricultural use. We did not include the types of pesticides used, because in the initial survey, almost all the women farmers did not clearly remember the pesticides used. The women only remembered the color and shape of the bottles of pesticides used, so we were not able to verify pesticide use by type. Regarding iodine levels, which can be related to diet, we did not collect food frequency or intake data. 


\section{Conclusions}

This study is the first study in Indonesia to examine the association of thyroid hormone levels between women farmers who may be exposed to pesticides and non-farmers. It is of clinical significance that we found that $64 \%$ of farmers were hypothyroid for FT3 (16\% were hypothyroid for FT4). Despite our hypothesis that the pesticide exposures of farming women would impact thyroid levels when compared to non-farmers, we found few significant differences in the distribution of clinical thyroid measures between farmers and non-farmers. However, simple t-tests and our multivariable models that included covariates showed that FT3 and T4 were significantly higher for farmers compared to non-farmers. Among farmers, $32 \%$ had low iodine levels. Although the government has launched an iodination program with iodized salt, there are still many farmers with low urinary iodine, possibly because of the choice of salt that is not iodized or has little iodine, or perhaps this is because the food consumed contains glucosinolates, which interfere with thyroid metabolism, thus exacerbating the effects of iodine deficiency.

To better understand any relationship between pesticide exposure and hormone function, future studies should measure pesticide biomarkers concurrently with target hormone levels.

Author Contributions: Conceptualization, D.M., W.N.K., P.K. and S.W. (Susan Woskie); Data curation, D.M. and L.L.; Formal analysis, D.M., L.L. and S.W. (Susan Woskie); Funding acquisition, W.N.K.; Investigation, D.M., S.W. (Sri Wuryanti) and H.M.; Methodology, D.M., L.L., H.H. and S.W. (Susan Woskie); Project administration, H.M. and F.N.J.; Resources, S.B., I.S. and Q.Q.; Software, D.M., L.L. and S.W. (Susan Woskie); Supervision, W.N.K. and S.W. (Susan Woskie); Validation, L.L.; Writing—original draft, D.M.; Writing—review and editing, D.M. and S.W. (Susan Woskie). All authors have read and agreed to the published version of the manuscript.

Funding: The research reported in this publication was supported by the Fogarty International Center of the National Institutes of Health under Award Number U2RTW010088. The content is solely the responsibility of the authors and does not necessarily represent the official views of the National Institutes of Health.

Institutional Review Board Statement: The study was conducted according to the guidelines of the Declaration of Helsinki and approved by The Ethical Committee Research Institute YARSI University (or Ethics Committee), before the study commenced (IRB number: 038/KEP-UY/BIA-IV/2019; date of approval was 26 April 2019).

Informed Consent Statement: Informed consent was obtained from all subjects involved in the study.

Data Availability Statement: Data from this study are available from the corresponding author on reasonable request.

Acknowledgments: The authors are very grateful to all participants in this study. We would like to thank the local Community Health Center staff for their assistance in recruiting research assistants and collecting data on subjects. The local health office has given permission for this research. The content is solely the responsibility of the authors and does not necessarily represent the official views of the National Institutes of Health.

Conflicts of Interest: The authors have no conflict of interest.

\section{References}

1. Direktorat Jenderal Tanaman Pangan. Use of Pesticides in Production and Food Safety Perspective. Kementerian Pertanian. 2020. Available online: http:/ /tanamanpangan.pertanian.go.id/index.php/iptek/16 (accessed on 19 December 2020).

2. Pusat Perlindungan Varietas Tanaman Dan Perizinan Pertanian. Pesticides in Indonesia. Kementerian Pertanian. 2020. Available online: http:/ / pvtpp.setjen.pertanian.go.id/cms2017/wp-content/uploads/2020/12/Pestisida-Erizal-Jamal-30-Des-2020 -materi.pdf (accessed on 19 December 2020).

3. Afriyanto, A.; Nurjazuli, N.; Budiyono, B. Keracunan Pestisida Pada Petani Penyemprot Cabe Di Desa Candi Kecamatan Bandungan Kabupaten Semarang. J. Kesehat. Lingkung. Indones. 2015, 8, 10-14.

4. Samosir, K.; Setiani, O.; Nurjazuli, N. Hubungan pajanan pestisida dengan gangguan keseimbangan tubuh petani hortikultura di Kecamatan Ngablak Kabupaten Magelang. J. Kesehat. Lingkung. Indones. 2017, 16, 63-69. [CrossRef]

5. Suhartono. Dampak Pestisida terhadap Kesehatan. Pros. Semin. Nas. Pertan. Organik 2014, 15-23. 
6. Nankongnab, N.; Kongtip, P.; Kallayanatham, N.; Pundee, R.; Yimsabai, J.; Woskie, S. Longitudinal study of thyroid hormones between conventional and organic farmers in Thailand. Toxic 2020, 8, 82. [CrossRef]

7. Kongtip, P.; Nankongnab, N.; Kallayanatham, N. Thyroid hormones in conventional and organic farmers in Thailand. Int. J. Environ. Res. Public Health 2019, 16, 2704. [CrossRef]

8. Suhartono, S.; Kartini, A.; Subagio, H.W.; Budiyono, U.A.; Suratman, S.; Sekundarno, M. Pesticide exposure and thyroid function in elementary school children living in an agricultural area, Brebes district, Indonesia. Int. J. Occup. Environ. Med. 2018, 9, 137-144. [CrossRef]

9. Goldner, W.S.; Sandler, D.P.; Yu, F.; Hoppin, J.A.; Kamel, F.; Levan, T.D. Pesticide use and thyroid disease among women in the agricultural health study. Am. J. Epidemiol. 2010, 171, 455-464. [CrossRef] [PubMed]

10. Farokhi, F.; Taravati, A. Pesticide exposure and thyroid function in adult male sprayers. Int. J. Med. Investig. 2014, 3, 127-133.

11. Kusumawati, R.; Suhartono, S.; Sulistyani, S. Beberapa faktor yang berhubungan dengan fungsi tiroid pada Pasangan Usia Subur (PUS) di Kecamatan Kersana Kabupaten Brebes. J. Kesehat. Lingkung. Indones. 2012, 11, 15-21.

12. Badan Pusat Statistik. The Result of Inter-Census Agricultural Survey 2018. BPS-Statistics. 2018, p. 79. Available online: https:// www.bps.go.id/publication/2019/01/02/c7cb1c0a1db444e2cc726708/hasil-survei-pertanian-antar-sensus--sutas--2018.html (accessed on 12 February 2020).

13. Badan Pusat Statistik. Harvest Area, Production, and Rice Productivity by Province. BPS-Statistics. 2018. Available online: https:/ / www.bps.go.id/dynamictable/2019/04/15/1608/luas-panen-produksi-dan-produktivitas-padi-menurut-provinsi2018.html (accessed on 12 February 2020).

14. Vidas TSH. Vidas. 30 400-01 vidas ${ }^{\circledR}$ TSH. 2015, Volume 1, pp. 1-7. Available online: https://www.scribd.com/document/472512 671/Vidas-TSH (accessed on 26 September 2019).

15. Vidas ${ }^{\circledR}$ FT3. Vidas. 30402 vidas ${ }^{\circledR}$ FT3. 2015, Volume 1, pp. 1-6. Available online: https:/ /www.scribd.com/document/42765359 6/Package-Insert-FT3-pdf (accessed on 26 September 2019).

16. Vidas FT4. Vidas. 30 401-01 vidas ${ }^{\circledR}$ FT4. 2015, Volume 1, pp. 1-7. Available online: https://www.scribd.com/document/423964 719/FT4-Insert (accessed on 26 September 2019).

17. Vidas T3. Vidas. 30 403-01 vidas ${ }^{\circledR}$ T3. 2015, Volume 6, pp. 1-8. Available online: https://www.scribd.com/document/41026233 7/T3-pdf-pdf (accessed on 26 September 2019).

18. Vidas. 30 404-01 vidas ${ }^{\circledR}$ T4. 2010, Volume 8, pp. 1-8. Available online: https://www.scribd.com/document/313310325/BVIDAS-T4-en (accessed on 26 September 2019).

19. Pangribowo, S. Hypertension the Silent Killer. Pusat Data dan Informasi Kementerian Kesehatan RI. 2019. Available online: https: / /pusdatin.kemkes.go.id/resources/download/pusdatin/infodatin/infodatin-hipertensi-si-pembunuh-senyap.pdf (accessed on 12 January 2020).

20. Kementerian Kesehatan RI. Body Mass Index (BMI) Threshold. Kementerian Kesehatan RI. 2020. Available online: http:/ /www. p2ptm.kemkes.go.id/infographic-p2ptm/obesitas/tabel-batas-ambang-indeks-massa-tubuh-imt (accessed on 12 January 2020).

21. Holil, M.P.; Sugeng, W.T. Nutritional Status Assessment. Pusat Pendidikan Sumber Daya Manusia Kesehatan Kementerian Kesehatan. 2017, p. 315. Available online: http://bppsdmk.kemkes.go.id/pusdiksdmk/wp-content/uploads/2017/11/ PENILAIAN-STATUS-GIZI-FINAL-SC.pdf (accessed on 12 January 2020).

22. Effendy, S.; Gunawan, M.F.; Lintang, D.; Argoputra, A.; Dian, P.; Abraham, Y.B. The Rerationship between Physical Activity Aan Obesity Based On Body Fat Percentage in Banjaroyo Village, Kalibawang, Kulon Progo, D.I. Yogyakarta. J. Farm. Sains. Dan Komunitas. 2018, 15, 29-36.

23. Pusat Data dan Informasi Kementerian Kesehatan RI. Thyroid Disease. Kementerian Kesehatan. 2015, Volume 8. Available online: https:/ / pusdatin.kemkes.go.id/resources/download/pusdatin/infodatin/infodatin-tiroid.pdf (accessed on 12 January 2020).

24. Kongtip, P.; Nankongnab, N.; Tipayamongkholgul, M.; Bunngamchairat, A.; Yimsabai, J.; Pataitiemthong, A.; Woskie, S. A crosssectional investigation of cardiovascular and metabolic biomarkers among conventional and organic farmers in Thailand. Int. J. Environ. Res. Public Health 2018, 15, 2590. [CrossRef]

25. Anand, M.; Singh, L.; Agarwal, P.; Saroj, R.; Taneja, A. Pesticides exposure through environment and risk of pre-term birth: A study from Agra city. Drug Chem. Toxicol. 2017, 42, 471-477. [CrossRef]

26. Ling, C.; Liew, Z.; Von, E.O.S.; Heck, J.E.; Park, A.S.; Cui, X.; Cockburn, M.; Wu, J.; Ritz, B. Prenatal exposure to ambient pesticides and preterm birth and term low birthweight in agricultural regions of California. Toxics 2018, 6, 41. [CrossRef]

27. Kementerian Kesehatan RI. Basic Health Research National Report 2018. Lembaga Penerbit Badan Penelitian dan Pengembangan Kesehatan. 2019. Available online: http://labdata.litbang.kemkes.go.id/images/download/laporan/RKD/2018/Laporan_ Nasional_RKD2018_FINAL.pdf (accessed on 12 January 2020).

28. Kongtip, P.; Nankongnab, N.; Mahaboonpeeti, R.; Bootsikeaw, S.; Batsungnoen, K.; Hanchenlaksh, C.; Tipayamongkholgul, M.; Woskie, S. Differences among Thai agricultural workers' health, working conditions, and pesticide use by farm type. Ann. Work Expo. Health 2018, 62, 167-181. [CrossRef]

29. Valencia, V.C.; Rodríguez, O.M.; Sandoval, M.E.V.; Bermúdez, J.A.; Castellanos, S.G.; Cruz, C.O.D.; Córdova, M.A.R. Prevalence of malnutrition-inflammation complex syndrome and its correlation with thyroid hormones in chronic haemodialysis patients. Nefrología 2018, 38, 57-63.

30. Koulouri, O.; Gurnell, M. How to interpret thyroid function tests. Clin. Med. 2013, 13, 282-286. 
31. Zoccali, C.; Mallamaci, F.; Tripepi, G.; Cutrupi, S.; Pizzini, P. Low triiodothyronine and survival in end-stage renal disease. Kidney Int. 2006, 70, 523-528. [CrossRef] [PubMed]

32. Xue, C.; Bian, L.; Xie, Y.S.; Yin, Z.F.; Xu, Z.J.; Chen, Q.Z. Low fT3 is associated with diminished health-related quality of life in patients with acute coronary syndrome treated with drug-eluting stent: A longitudinal observational study. Oncotarget. 2017, 8, 94580-94590. [CrossRef] [PubMed]

33. Gostas, D.E.; Meyer, D.E.L.; Yoder, H.A.; Hu, A.E.; Johnson, E.C. Dietary relationship with 24 h urinary iodine concentrations of young adults in the mountain west region of the United States. Nutrients 2020, 12, 121. [CrossRef] [PubMed]

34. Tamang, M.K.; Gelal, B.; Tamang, B.; Lamsal, M.; Brodie, D.; Baral, N. Excess urinary iodine concentration and thyroid dysfunction among school age children of eastern Nepal: A matter of concern. BMC Res. Notes 2019, 12, 294. [CrossRef] [PubMed]

35. Zimmermann, M.B. Iodine Deficiency. Endocr. Rev. 2009, 30, 376-408. [CrossRef] [PubMed]

36. Mulalazimah, M.; Mulyono, B.; Murti, B.; Azwar, S. Asupan Yodium, Ekskresi Yodium Urine, dan Goiter pada Wanita Usia Subur di Daerah Endemis Defisiensi Yodium. J. Kesehat. Masy. Nas. 2013, 8, 139-144.

37. Gargari, S.S.; Fateh, R.; Bakhtiari, M.B.; Saleh, M.; Mizamoradi, M.; Bakhtiyari, M. Maternal and neonatal outcomes and determinants of iodine deficiency in third trimester of pregnancy in an iodine sufficient area. BMC Pregnancy Childbirth 2020, 20, 174. [CrossRef] [PubMed]

38. Braverman, L.E.; Lueng, A.M. Consequences of excess iodine. Nat. Rev. Endocrinol. 2014, 10, $136-142$. 